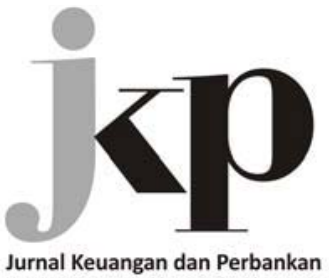

UNIVERSITY OF MERDEKA MALANG

\section{Article history:}

Received: 2020-00-00

Revised: 2018-00-00

Accepted: 2018-00-00

\section{Keywords:}

Bank's performance; Boardroom; Gender diversity; Two-tier; Woman

JEL Classification: G20, M41, M48

\section{Kata Kunci:}

Kinerja bank; Ruang rapat; Perbedaan gender; Dua tingkat; Wanita

\title{
The impact of gender diversity in the boardroom on banks performances
}

\author{
Siti Farhana \\ Department of Management, Faculty of Economics and Business, Universitas Prasetiya Mulya \\ BSD Kavling Edutown, Jakarta, 15339, Indonesia
}

\begin{abstract}
This research examined the impact of gender diversity in the boardroom on firm performance using banks listed on the Indonesia Stock Exchange (IDX) in the period from 2011 to 2016. Indonesia listed companies have a two-tier board structure that consist of management and supervisory board. In addition, listed companies should establish a committee board that consists of independent directors from outside the company. Thus, we investigate the gender diversity from each boardroom namely management, supervisory, and committee board. Gender diversity is measured by the Blau Index while bank's financial performances are proxied by the Return on Assets (ROA) and Capital Adequacy Ratio (CAR). These two measurements are required by Indonesian Financial Service Authority or Otoritas Jasa Keuangan (OJK). We find that the average proportion of female directors sitting on management, supervisory, and committee board in banks are 16 percent, 9.7 percent, and 14 percent, respectively. Applying panel data analysis with fixed and random effect estimator and also addressing endogeneity issue, we find that there is no significant relationship between gender diversity indexes in each boardroom and both bank's financial performance $R O A$ and CAR. These findings may shed a light for regulator in Indonesia especially OJK whether they consider imposing gender quota in the boardroom.
\end{abstract}

\section{Abstrak}

Penelitian ini mengkaji dampak keberagaman gender di ruang direksi terhadap kinerja perusahaan pada bank-bank yang terdaftar di Bursa Efek Indonesia (BEI) periode 2011-2016. Perusahaan yang terdaftar di Indonesia memiliki struktur dewan dua tingkat yang terdiri dari dewan pengurus dan pengawas. Selain itu, emiten harus membentuk dewan komite yang terdiri dari direktur independen dari luar perusahaan. Karenanya, kami menyelidiki keragaman gender dari setiap ruang rapat yaitu manajemen, pengawas, dan dewan komite. Keragaman gender diukur dengan Indeks Blau, sedangkan kinerja keuangan bank diproksikan dengan Return on Assets (ROA) dan Capital Adequacy Ratio (CAR). Kedua ukuran ini diwajibkan oleh Otoritas Jasa Keuangan (OJK). Kami menemukan bahwa rata-rata proporsi direksi perempuan yang menduduki jabatan pengurus, pengawas, dan dewan komite di Bank masingmasing adalah 16 percent, 9,7 persen, dan 14 persen. Menerapkan analisis data panel dengan penaksir efek tetap dan acak serta mengatasi masalah endogenitas, kami menemukan bahwa tidak ada hubungan yang signifikan antara indeks keragaman gender di setiap ruang rapat dengan ROA dan CAR kinerja keuangan kedua bank. Temuan ini dapat menjadi titik terang bagi regulator di Indonesia khususnya OJK apakah mempertimbangkan untuk memberlakukan kuota gender di ruang rapat.

How to Cite: Farhana, S. (2020). The impact of gender diversity in the boardroom on
banks performances. Jurnal Keuangan dan Perbankan, 24(4), 434-448. https://doi.org/10.26905/jkdp.v24i4.4676

$\triangle$ Corresponding Author:

\section{Siti Farhana:}

Tel. 085692226612

E-mail:

siti.farhana@prasetiyamulya.ac.id

article under the CC-BY-SA license 


\section{The impact of gender diversity in the boardroom on banks performances}

Siti Farhana

\section{Introduction}

In recent years, many countries have paid special attention to diversity in the boardroom, which has been deemed as one of the indicators of good corporate governance practice (CGIO, 2012). MelónIzco et al. (2020) also found that board diversity shows the efficiency of corporate governance mechanism. Van Knippenberg et al., (2004) defined board diversity as ensuring heterogeneity among the directors. These authors confirmed that heterogeneity varies according to age, nationalities, religion, gender, and functional skills. Among the variations of board diversity, gender diversity has become the most important topic for many firms across many countries (Carter et al., 2003).

In responding to gender diversity, some countries have initiated a set gender quota for female in boardroom. Norway was the first country in this respect, which in 2006 enforced a gender quota in the boardroom for listed companies. Norwegian corporations were required to have a minimum of $40 \%$ of female's board members by 2008 (Farag \& Mallin, 2016). Besides Norway, Sweden has also initiated a set quota for female representing 25 percent of total boards, but this was a voluntarily requirement (Rao \& Tilt, 2015). In contrast, Spain applied comply or explain system which require the quota of female to make up a total of 40 percent of board directors by 2015 (Rao \& Tilt, 2015). Many other countries, such as Italy and France, have also adopted a similar approach to gender quotas in the boardroom (Rao \& Tilt, 2015). However, in the case of Asia, especially Indonesia, the regulators do not require gender quota for female directors in board room in listed companies, despite the fact that in the legislative house, government mandates through regulation Law No.12 of 2013 that 30 percent of the members should be female. From the overview of the efforts by some countries to impose a gender quota in the boardroom, it is clear that gender diversity within this environment requires special attention.
Consequently, many research studies have been undertaken by researchers to examine the impact of gender diversity in the boardroom. The most prevalence of these has been focused on firm performance. Prior research by McKinsey (2012) and Credit Suisse (2012) revealed that companies with more female directors tend to have better performance, when measured by ROE. Furthermore, Garcia-Meca et al. (2015) found female in boardroom create better performance in Bank. In contrast, Adam \& Ferreira (2009) found a negative relationship between gender diversity and ROA. In addition, Ellwood \& Garcia-Lacalle (2015) did not find an association between gender diversity and firm financial performance when measured by $R O A$.

Therefore, it is apparent the findings are mixed, and most studies are having been conducted extensively in developed countries with only a few studies addressing the issue in emerging countries. Thus, to address this gap, this paper aims to examine the impact of gender diversity in the boardroom on firm performance in Indonesia. Indonesia, as an emerging country, has a different economic, legal, social, and cultural environment compared to developed countries. Furthermore, as aforementioned, Indonesia still does not have regulations about female quota in boardrooms, unlike those in European countries. In addition, Indonesia is unique compared to other Asian countries because it has adopted two-tier board structure (OJK, 2014). It separates supervisory and management board. Members of which are both appointed by shareholders. This makes Indonesia quite different from many European countries who also adopt two-tier board structure, because generally in these European countries management board directors are elected by supervisory board directors.

Regarding female directors in the board room In Indonesia, as of 2011, out of 3,729 board positions in listed firms in IDX3, 432 positions were occupied by women, which interestingly places Indonesia at the top of the rankings for the number of 
women in the boardrooms in Asia (CGIO, 2012). The banking sector is one where women are most represented in the boardroom (CGIO, 2012). In addition, the banking sector is also the most regulated industry in Indonesia. OJK, the Financial Service Authority in Indonesia, monitors banks' performance and governance mechanism strictly and closely. Apart from the supervisory and management board, banks are also mandated by OJK regulation to have committee boards such as an Audit Committee, Risk Monitoring Committee, and Nomination and Remuneration Committees. Accordingly, examining the Indonesia context is interesting and thus motivated the researcher to find the evidence as regarding whether gender diversity in management, supervisory, and committee boards have an effect on firm performance in the banking sector in Indonesia.

\section{Hypotheses Development}

The board diversity topic, especially gender diversity, has become popular over the past few years and has attracted many scholars to study empirically. Most studies have been conducted in the one-tier system of board structure areas, namely the US and UK capital market, with only a few studies conducted in two-tier system countries. It is worthy to note that studies conducted in most onetier countries use term board, which emphasises more on a function of the supervisory board in Indonesia (Pudjiastuti \& Mardiyah, 2007). Thus, in any study results from one-tier countries that mention board, this is similar to board of commissioners in Indonesia.

The World Bank report (2010) shows that employing more females and minimising the gender gap in employment could lead a country to sustain its long-term economic growth and wealth, enhance governance, and improve living standards. Ali et al. (2014) studied the differences between men and women in a boardroom and mentioned that men and women have distinctive characteristics in rela- tion to skills, knowledge, and perspective, and the collaboration of those characteristics will lead to higher quality decisions. Other studies have also found that the presence of women directors encourages more participative conversations among members, which lead to broader perspectives, ideas generation and innovation (Bear et al., 2010).

\section{Female directors in management board (board of directors) and bank's performance}

Due to two-tier structure system, Indonesia has separated management and supervisory board. The management board is responsible for running day-to-day operations (KNKG, 2006) and is expected to be financially successful (Ali et al., 2014). A prior study conducted by Darmadi (2013) found female directors in samples of all companies listed in IDX have a negative relationship with firm performance when measured with Tobin's $\mathrm{Q}$ and ROA. He argues that the nature of firms in Indonesia is familyowned (Credit Suisse, 2012) in which company can appoint female directors based on family relationship rather than experience or skill. Clearly, a lack of experience or skill may adversely affect firm's performance. Similarly, 70 percent of private banks in Indonesia are also family-owned (Bank Indonesia, 2011), and these owners may also appoint female directors based on family ties. However, the appointment of directors (female or male) should pass OJK approval and must succeed in the Fit and Proper Test. Therefore, we argue that only candidates with capability may pass the test. In addition, referring to the stewardship theory, females are argued as good stewards to shareholders because they pay more attention to collaboration, personnel development, communication, and networking (Claes, 1999; Low et al., 2015). Thus, we predict having more women on management board will increase firm's performance.

$H_{1}$ : there is a positive relationship between gender diversity in management boards and bank's financial performance 


\section{Female directors in supervisory board (board of commissioners) and bank's performance}

There are several studies that show the positive correlation of gender diversity on firm performance. Romano et al. (2012) also concluded that female presence on boards have a positive correlation with bank performance in Italy, as measured by ROE and ROA. They suggested that the presence of female directors could improve bank performance because they contribute to a large pool of skills, competencies, knowledge, and networks. A more recent study by Garcia-Meca et al. (2015) found women directors has a positive and significant impact on bank performance when measured by Tobin's q, using a sample of banks in nine countries. Gulamhussen \& Santa (2015) also concluded that female board have significant impact on bank's performance.

Contrastingly, Adam \& Ferreira (2009), using a sample of US firms, found that gender diversity has a negative relationship with ROA and Tobin's q. They speculated that more females in a board room could lead to over monitoring for companies that already have good governance in place.

In contrast, the study by Mori (2014) indicated that there is no effect on female directors on microfinance institution performance based on a sample in East Africa. She suggested this was due to the dataset containing only 23 percent of female directors. Similarly, Ellwood \& Garcia-Lacalle (2015) did not find an association between gender diversity and firm financial performance. They argued that the presence of female directors did affect much on financial return. FathIn addition, a study by Joecks et al. (2012), which examined the relationship between gender diversity and firm performance for a sample of Germany companies, is worth noting. They found evidence for the relationship between gender diversity and firm performance, which, measured in $R O A$, is in U-shaped and that to realise the advantage of gender diversity (increased ROE), a company has to have at least three women sitting in the boardroom.
A similar study had been conducted in Indonesia using a sample of non-financial listed firms by Pudjiastuti \& Mardiyah (2007). They found a negative relationship between female commissioners and firm performance measured with ROE and Tobin's Q. We argue that this happened due to weak corporate governance mechanism in companies other than banking sector. The argument is substantiated by Prihatiningtias (2012), who claimed the negative relationship between gender diversity in the boardroom and financial performance might be caused due to the weaknesses of corporate governance. Contrastingly, Fathonah (2018) found no relationship between female boards in twelve manufacturing firms and firm performance measured with current ratio. However, in the case of the banking sectors, the governance mechanism is extraordinarily strong. Banks are required to hire independent commissaries in supervisory board at least 50 percent of the total. Referring to the agency theory, which argues that board diversity leads to better monitoring and advising managers, directors in a supervisory board is expected to reduce agency problem and consequently this will improve firm performance (Thomsen \& Conyon, 2012). Thus, one can expect that shareholders will be very selective in appointing the supervisory board directors. Farrell \& Hersch (2005) claim females are tougher monitors and more detailed focused in evaluating management boards (Stendardi et al., 2006). Thus, we predict female directors in supervisory board will play their role as good and tougher monitors and lead to improve firm performance.

$\mathrm{H}_{2}$ : there is a positive relationship between gender diversity in supervisory boards (called female commissioners) and bank's financial performance

\section{Female committees and bank's performance}

In respect of the committee board, according to the resource dependence theory, the board is regarded as resources provider for companies. 
Therefore, more diversity of the board means more resources are available in the company, which could lead to efficient resource utilisation (Jensen, 1993) and useful for decision making. Carter et al. (2010) claims that the presence of women in boards also provides different resources and benefits and improves firm performance. In the case of banks, through regulation number 55/POJK.03/2016, OJK requires banks to have audit committee, risk monitoring committee, and remuneration and nomination committee with each committee consisting of at least 3 members. The leader of each committee has to be independent commissioners and two members are required from external parties who are independent of the companies with have diverse backgrounds. Independent commissioners or committees are, by nature, effective at monitoring and advising management the boards and females are deemed as good and tougher monitors and they pay attention to the detail (Stendardi et al., 2006). Thus, one can expect female committees will contribute to firm performance.

$H_{3}$ : there is a positive relationship between gender diversity in committee boards and bank's financial performance

\section{Method, Data, and Analysis}

\section{Sample and population}

The samples for this study are banks listed in Indonesia Stock Exchange (IDX) during 2011-2016. We employed purposive sampling, in light of specific considerations, in determining the sample. The considerations were: (1) banks listed in IDX in the period 2011-2016; (2) banks continuously publish-

Table 1. Sample selection

\begin{tabular}{lc}
\hline \multicolumn{1}{c}{ Criteria } & Number of observations \\
\hline Total banks in period 2011-2016 & 713 \\
Total banks listed in period 2011-2016 & 218 \\
Total banks publish annual report in 5 consecutive years & 174 \\
Total banks are not delisted in period 2011-2016 & 174 \\
Final total observations & 174 \\
\hline
\end{tabular}

Table 2. Summary of variables

\begin{tabular}{|c|c|}
\hline Variables & Definition \\
\hline \multicolumn{2}{|l|}{ Dependent variables } \\
\hline$R O A$ & $\begin{array}{l}\text { Annual net income before extraordinary items and discontinued } \\
\text { operations divided by total assets at the end of the year }\end{array}$ \\
\hline CAR & Total capital over risk-weighted asset \\
\hline \multicolumn{2}{|l|}{ Independent variables } \\
\hline BlauSB & Gender diversity index in supervisory board measured by Blau Index \\
\hline BlauMB & Gender diversity index in management board measured by Blau Index \\
\hline BlauCB & Gender diversity index in committee board measured by Blau Index \\
\hline \multicolumn{2}{|r|}{ 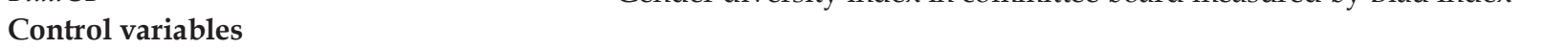 } \\
\hline Firm size $(F S I Z E)$ & Natural logarithm of the asset book value \\
\hline Financial leverage $(L E V)$ & Ratio of total debt to total asset \\
\hline Type of ownership (D1, D2, D3) & $\begin{array}{l}\text { Dummy variable } D 1=\text { state-owned bank, } D 2=\text { foreign-owned bank, } D 3= \\
\text { private-owned bank }\end{array}$ \\
\hline Ownership structure $(O W N)$ & Dummy variable, $1=$ controlled by family, $0=$ otherwise \\
\hline Supervisory board size (Ssize) & Total directors in supervisory board/Total Board of Commissioners \\
\hline Management board size (Msize) & Total directors in management board/Total of Board of Directors \\
\hline
\end{tabular}


ing the annual report and corporate governance report on an annual basis for at least five consecutive years; (3) banks not delisted in the period 2011-2016; and (4), financial statement ended December 31. The time period from 2011 to 2016 was chosen to allow for the possible impact of gender diversity on bank's financial performance. This study used secondary data with the primary data source for gender diversity in the boardroom was from annual reports and Indonesia Banking Directory published by OJK; while the data source for bank's financial performance was retrieved from Thomson Financial Datastream. The final numbers of observations are presented in Table 1.

\section{Method}

The following Table 2 provides an overview of the variables adopted in the current study. Banks performance as dependent variable are proxied by return on asset $(R O A)$ and capital adequacy ratio $(C A R)$. The independent variables in this study were the gender diversity in the management, supervisory, and committee board. We used the Blau Index to measure the gender diversity in each boardroom. The Blau Index was applied because it is commonly used to measure the variety such as gender, age, education, and experience, and the level of diversity among the group (Harrison \& Sin, 2006; Prihatiningtias, 2012). It was also used in previous studies to measure the gender diversity (Bear et al., 2010; Joecks et al., 2012; Farag \& Malin, 2016). The value of Blau Index ranges from 0 to 0.5 . Zero value means the board is homogenous (either all directors are male or all directors are female) while 0.5 value means the proportion between female and male directors is balanced.

In order to examine the association between gender diversity and bank financial performance, using data from 2011-2016 time period, panel data analysis was employed. In examining these relationships, Hermalin \& Weisbach (2003) claim that endogeneity problems may arise and can lead to the spurious correlation between variables. In addition, Carter et al. (2003); Ali et al. (2014); and Low et al. (2015) contend that there is a possibility of reverse causality when examining the impact of gender diversity on firm performance that will also lead to endogeneity problems. Accordingly, we run panel data regression with fixed effect and random effect to examine the existence of a correlation between unobservable heterogeneity and explanatory variables (Campbell \& Vera, 2008). The Hausman test was also required to determine whether a fixed effect or random effect would be employed (Farag \& Malin, 2016). In addition, to control for potential reverse causality, panel data with 2SLS (two-stage least squares) regression was required for estimation (Carter et al., 2003).

Considering the endogeneity issue, to estimate the association between gender diversity and bank's performance we employ two models. First model is employing $R O A$ and $C A R$ as dependent variables and gender diversity index as independent variables. We include firm size, leverage, dummy variable for family-controlled bank and type of ownership, and control for firm-fixed and yearfixed effect. Thus, the equations are as follows:

$$
\begin{aligned}
& \text { ROA }_{i, t}=\alpha+\beta_{1} \text { BlauSB }_{i, t}+\beta_{2} \text { BlauMB }_{i, t}+\beta_{3} \text { BlauCB }_{i, t-1}+\beta_{4} \text { FSIZE }_{i, t} \\
& +\beta_{5} L E V_{i, t}+\beta_{6} O W N_{i, t}+\beta_{7} D 1_{i, t}+\beta_{8} D 2_{i, t}+\beta_{9} D 3_{i, t}+ \\
& \beta_{10} \text { firm fixed effect }+\beta_{11} \text { year fixed effect }+\varepsilon_{i, t} \\
& \mathrm{CAR}_{i, t}=\alpha+\beta_{1} \text { BlauSB }_{i, t}+\beta_{2} \text { BlauMB }_{i, t}+\beta_{3} \text { BlauCB }_{i, t-1}+\beta_{4} \text { FSIZE }_{i, t} \\
& +\beta_{5} L E V_{i, t}+\beta_{6} O W N_{i, t}+\beta_{7} D 1_{i, t}+\beta_{8} D 2_{i, t}+\beta_{9} D 3_{i, t}+ \\
& \beta_{10} \text { firm fixed effect }+\beta_{11} \text { year fixed effect }+\varepsilon_{i, t}
\end{aligned}
$$

In the second model is we set $R O A$ and CAR as independent variables and the gender diversity index as dependent variables to eliminate the possibility of reverse causalities (Ali et al., 2014). We examined whether firms with better performance (higher ROA or CAR) will induce firms to hire female directors. Following Ali et al. (2014) work, we regress dependent and independent variables with- 
out control variables. We also used lagged $R O A$ and $C A R$ in regression. The rationale is previous bank's performance impact the gender diversity in following year. Accordingly, the regression models are:

$\begin{aligned} \text { BlauMBi,t= } & \alpha+\beta_{1} \text { ROAi,t-1 }+\beta_{2} \text { CARi,t-1 }+\beta_{3} \text { firm fixed effect }+ \\ & \beta_{4} \text { year fixed effect }+\varepsilon_{i, t}\end{aligned}$

BlauSBi, $t=\alpha+\beta_{1}$ ROAi,t-1 $+\beta_{2}$ CARi,t $-1+\beta_{3}$ firm fixed effect + $\beta_{4}$ year fixed effect $+\varepsilon i, t$

BlauCBi,t $=\alpha+\beta_{1} R O A i, t-1+\beta_{2} C A R i, t-1+\beta_{3}$ firm fixed effect + $\beta_{4}$ year fixed effect $+[i, t$

\section{Results}

Table 3 tabulates the descriptive statistics for the dependent, independent, and control variables used in the regression. There are several things to consider from the results presented in Table 3.

First, the absence of women in boardroom still existed in Indonesian banks during the 2011-2016 period. The absence of women can be shown from the minimum number (column 4) in BlauMB, BlauSB, and Blau $C B$ (and also $\% M B, \% S B$, and $\% C B$ ). From the data, the minimum score of Blaun Index (BlauMB, BlauSB and BlauCB) means more male directors are in the boardroom. Second, from our observations, the management board has the highest average (column 2) of women sitting in the boardroom (denote with \%MB). It is shown to be 16 percent, while in supervisory $(\% S B)$ and committee board $(\% C B)$ the average is 9.6 percent and 14 percent, respectively. This result supports the CGIO (2011) findings that suggest most women hold director positions in management board. Third, the minimum number of supervisory board (Ssize) is only two. There are two explanations for this case. First, the particular bank(s) just does (do) not comply with the regulation published by OJK, which require a minimum three directors to sit on the supervisory board. Another explanation is the potential directors are yet to be approved by the OJK (due to fit and proper test), so the position of the director is still deemed as vacant.

Table 3. Statistic summary

\begin{tabular}{|c|c|c|c|c|c|}
\hline Variable & $\begin{array}{l}(1) \\
N\end{array}$ & $\begin{array}{c}(2) \\
\text { Mean }\end{array}$ & $\begin{array}{c}\text { (3) } \\
\text { Std. Dev. }\end{array}$ & $\begin{array}{c}\text { (4) } \\
\text { Min. }\end{array}$ & $\begin{array}{c}(5) \\
\text { Max. }\end{array}$ \\
\hline \multicolumn{6}{|l|}{ Dependent Variables } \\
\hline$R O A$ & 174 & 0.0101 & 0.0199 & -0.117 & 0.0968 \\
\hline CAR & 174 & 0.172 & 0.0442 & 0.0802 & 0.458 \\
\hline \multicolumn{6}{|l|}{ Independent Variables } \\
\hline$\% M B$ & 174 & 0.160 & 0.165 & 0 & 0.625 \\
\hline$\% S B$ & 174 & 0.0966 & 0.130 & 0 & 0.500 \\
\hline$\% C B$ & 174 & 0.140 & 0.123 & 0 & 0.556 \\
\hline BlauMB & 174 & 0.215 & 0.193 & 0 & 0.500 \\
\hline BlauSB & 174 & 0.141 & 0.174 & 0 & 0.500 \\
\hline BlauCB & 174 & 0.210 & 0.160 & 0 & 0.496 \\
\hline \multicolumn{6}{|l|}{ Control Variables } \\
\hline OWN & 174 & 0.397 & 0.491 & 0 & 1 \\
\hline D1 & 174 & 0.218 & 0.414 & 0 & 1 \\
\hline D2 & 174 & 0 & 0 & 0 & 0 \\
\hline D3 & 174 & 0.747 & 0.436 & 0 & 1 \\
\hline FSIZE & 174 & 17.54 & 1.621 & 14.55 & 20.76 \\
\hline SIZE & 174 & 12.33 & 4.032 & 5 & 20 \\
\hline Msize & 174 & 7.011 & 2.501 & 3 & 12 \\
\hline Ssize & 174 & 5.316 & 1.871 & 2 & 11 \\
\hline$L E V$ & 174 & 0.878 & 0.0392 & 0.735 & 0.992 \\
\hline
\end{tabular}

$\% M B, \% S B$, and $\% S C$ are the percentage of female directors in respective boardsSIZE is the total management and supervisory board 
Another issue to highlight is the maximum of total board size (SIZE). In this study, the observations are 20. Since there is no regulation about the number of boards, thus it is the company's (shareholders) discretion to decide on how many members they will hire. The maximum number of the supervisory board (Ssize) is 11, which is close to the maximum number of the management board (Msize), 12. This means banks, especially their shareholders, regard the role of monitoring (supervisory board) as important as the operation role (management board). However, the mean of board size in this observation is greater than Prihatiningtias's finding (2012) who found the average directors in a boardroom in financial institutions was 8 over the period 2005-2008. The possible reason is she included all banks, insurance and leasing companies into her sample regardless of whether they were listed or not in IDX, therefore, this does not rule out the possibilities that the small firms were included (the minimum of total log asset in her sample is only 8.63 while in this study sample is 14.55). Another thing to highlight is that D2 (dummy for foreign-owned bank) is zero in all aspects. This is

Table 4. Main regression

\begin{tabular}{|c|c|c|c|c|c|}
\hline Variables & $\begin{array}{c}(1) \\
R O A\end{array}$ & $\begin{array}{c}(2) \\
C A R\end{array}$ & $\begin{array}{c}(3) \\
\text { BlauMB }\end{array}$ & $\begin{array}{c}(4) \\
\text { BlauSB }\end{array}$ & $\begin{array}{c}(5) \\
\text { BlauCB }\end{array}$ \\
\hline BlauMB & $\begin{array}{r}0.0023 \\
(0.0240)\end{array}$ & $\begin{array}{r}0.0075 \\
(0.0215)\end{array}$ & & & \\
\hline BlauSB & $\begin{array}{r}0.0518 \\
(0.0414)\end{array}$ & $\begin{array}{r}-0.0276 \\
(0.0218)\end{array}$ & & & \\
\hline BlauCB & $\begin{array}{r}-0.0060 \\
(0.0138)\end{array}$ & $\begin{array}{r}-0.0361 \\
(0.0370)\end{array}$ & & & \\
\hline OWN & $\begin{array}{r}0.0136 \\
(0.0108)\end{array}$ & $\begin{array}{r}-0.0312 \\
(0.0259)\end{array}$ & & & \\
\hline D1 & $\begin{array}{r}0.0352^{* * *} \\
(0.0107)\end{array}$ & $\begin{array}{r}-0.1464^{* * *} \\
(0.0225)\end{array}$ & & & \\
\hline D3 & & $\begin{array}{r}-0.0906^{* * *} \\
(0.0136)\end{array}$ & & & \\
\hline FSIZE & $\begin{array}{r}0.0094 \\
(0.0090)\end{array}$ & $\begin{array}{r}-0.0218 \\
(0.0236)\end{array}$ & & & \\
\hline$L E V$ & $\begin{array}{r}-0.0629 \\
(0.1131)\end{array}$ & $\begin{array}{r}-0.8146^{* * *} \\
(0.2573)\end{array}$ & & & \\
\hline ROA & & & $\begin{array}{r}-1.3336 \\
(1.3426)\end{array}$ & $\begin{array}{r}-0.5362 \\
(0.6636)\end{array}$ & $\begin{array}{r}-0.3024 \\
(0.2551)\end{array}$ \\
\hline CAR & & & $\begin{array}{r}-0.1968 \\
(0.3965)\end{array}$ & $\begin{array}{r}-0.3449 \\
(0.3309)\end{array}$ & $\begin{array}{r}0.0650 \\
(0.1829)\end{array}$ \\
\hline Constant & $\begin{array}{r}-0.1288 \\
(0.1685)\end{array}$ & $\begin{array}{r}1.3111^{* * *} \\
(0.4615)\end{array}$ & $\begin{array}{r}0.0730 \\
(0.0920)\end{array}$ & $\begin{array}{r}0.0722 \\
(0.0724)\end{array}$ & $\begin{array}{r}0.2457^{* * *} \\
(0.0387)\end{array}$ \\
\hline Observations & 174 & 174 & 174 & 174 & 174 \\
\hline R-squared & 0.1666 & 0.6446 & 0.0758 & 0.1439 & 0.1453 \\
\hline Hausman Test & 39.8 & 12.55 & 9.96 & 1.06 & 89.41 \\
\hline Number of gvkey & 29 & 29 & 29 & 29 & 29 \\
\hline Year FE & YES & YES & YES & YES & YES \\
\hline Firm FE & YES & YES & YES & YES & YES \\
\hline
\end{tabular}

Robust standard errors in parentheses. Notes: ${ }^{* * *} \mathrm{p}<0.01,{ }^{* *} \mathrm{p}<0.05,{ }^{*} \mathrm{p}<0.1$ indicate the significance. Both $R O A$ and CAR as independent variables (regression for column 3,4, and 5) are measured in lagged (t-1). 2SLS panel data regression of gender diversity (BlauMB, BlauSB, BlauCB) and bank's performance $(R O A$ and $C A R)$ 
because, from the observations it appeared that no banks listed in IDX during the 2011-2016 period appeared as foreign owned. Moreover, CAR varies from 8 percent to 45 percent, which is a good indication, as banks in this observation are all financially healthy. The rationale accords to OJK regulations that banks should maintain $C A R$ above 8 percent to be regarded as financially healthy.

Table 4 shows the empirical result for the regression in this research. At first, we ran Hausman Test to identify whether the fixed or random effect estimator should be used in these panel data set. For both model 1 and 2, the results of Hausman Test are Prob $>$ chi $2=0.0003$ and Prob $>$ chi $2=0.4087$ respectively, which suggests for model 1 , the use of fixed effects estimator is preferable while for model 2 , the random fixed effect is more appropriate. We also controlled for firm and year fixed effect in the regression. In Table 4 column (1) and (2), we do not find evidence that gender diversity in management, supervisory, and committee board have an association with both $R O A$ and $C A R$. The p-values are above the significance level at 10 percent. Based on this result, $H_{1}, H_{2}$ and $H_{3}$ are rejected. Another finding to highlight is that leverage has a negative relationship with $C A R(p<0.001)$. This indicates high leverage will impair firm performance measured with $C A R$. However, we found equivocal evidence in the association between $D 1$ (dummy variable for the state-owned bank) and both ROA and CAR.

\section{Robustness test}

As mentioned in the previous section, endogeneity problem is inevitably when to examine the relationship between corporate governance and firm performance. Therefore, we have to conduct several additional tests to address this issue. First, we address by including both firm-fixed and year-fixed effect in our regression to control for firm and year specific characteristic. Second, we argue that the possibility of the association between female directors and firm performance may be jointly or endogenously determined. Thus, following Ali et al. (2014), we perform reverse causality test by using panel data with 2SLS regression. In Table 5 column (3), (4), and (5), the results show that both $R O A$ and $C A R$ do not predict gender diversity in supervisory, management, and committee board. In addition, we use alternative measurement for bank's performance and gender diversity to detect whether the result remains robust. We use ROE as an alternative measurement for bank's financial performance and for gender diversity, we use dummy variable. The result of the regression is tabulated in Table 5 . We can see from Table 5 the result remains robust that gender diversity has no impact on bank's financial performance.

Table 5. Robustness test

\begin{tabular}{|c|c|}
\hline Variables & ROE \\
\hline$M B$ & $\begin{array}{r}0.0506 \\
(0.0609)\end{array}$ \\
\hline$S B$ & $\begin{array}{r}0.0225 \\
(0.0609)\end{array}$ \\
\hline$C B$ & $\begin{array}{r}0.0153 \\
(0.0393)\end{array}$ \\
\hline OWN & $\begin{array}{r}0.1251 \\
(0.1118)\end{array}$ \\
\hline D1 & $\begin{array}{r}-0.3397^{* * * *} \\
(0.0672)\end{array}$ \\
\hline D3 & $\begin{array}{r}0.0706^{* * *} \\
(0.0243)\end{array}$ \\
\hline FSIZE & $\begin{array}{r}0.1620 \\
(0.1132)\end{array}$ \\
\hline$L E V$ & $\begin{array}{r}0.5507 \\
(0.7000)\end{array}$ \\
\hline Constant & $\begin{array}{r}-3.2177^{* * *} \\
(1.6397)\end{array}$ \\
\hline Observations & 174 \\
\hline $\begin{array}{l}\text { Number of } \\
\text { gvkey }\end{array}$ & 29 \\
\hline Year FE & YES \\
\hline Firm FE & YES \\
\hline Hausman Test & 17.28 \\
\hline
\end{tabular}

To check the results of main regression remain robust, we apply another regression with different measurements. The independent variable (a proxy for firm performance) is Return on Equity, denoted with ROE while for the independent variables (proxy for female directors) are using dummy variables whether in each board female directors are present, denoted with $M B, S B$, and $C B$ Robust standard errors in parentheses. Notes: ${ }^{* * *} \mathrm{p}<0.01,{ }^{* *} \mathrm{p}<0.05, * \mathrm{p}<0.1$ indicate the significance 


\section{The impact of gender diversity in the boardroom on banks performances}

Siti Farhana

\section{Discussion}

From the results, we find the evidence that the gender diversity in the boardrooms (supervisory, management, and committee board) do not affect differently on bank performance. They all have no relationship with bank financial performance. The findings of no influence on the performance of gender diversity are in line with the studies of Ghosh (2017), Ellwood \& Garcia-Lacalle (2015) and Marinova et al. (2015).

In the management board, we do not find any significant link between gender diversity and firm performance when measured by ROA and CAR. The possible explanation is that most females in management board in this sample do not occupy critical positions. Only six banks (out of 29 banks) in our sample do not have female directors in management board. Thus, the remaining 23 banks have women directors in management board of which 17 banks have women assigned as Human Capital Management, Compliance, or IT Directors. These functions can be categorised as corporate or support functions, which contribute indirectly to firm performance (PWC, 2013). The Financial Stability Board (FSB, 2013) define critical positions in financial institutions as a position that is responsible for activities performed for third parties such as consumer, debtor, and creditor, where failure or making mistake will result in financial system and economy instability. Those positions are regarded as high risk (Beames, 2016). In addition, Beames (2016) argue that critical position should have value creation and be linked to business strategy. Accordingly, the examples of critical position in banks contains activities such as payments, lending and deposit activities, custody, clearing and settling, strategy, and risk management (FSB, 2013). Those critical positions are mostly assigned to males. In this sample, 23 banks out of 29 banks have males in those critical positions. This outcome is supported by Shrader et al. (1997), who argue women in boards tend to be assigned to less impact position in the firm. Similarly, Kanter (1977) argued that women are usually assigned to the conventional position regardless of their qualifications. She also argues that women are often placed as tokens in a firm just because of the need to have female directors in the boardroom.

Another explanation is that the tenure that women hold in boardrooms in this sample is not long enough to realise the impact of gender diversity on firm performance. In this sample period from 2011-2016, the average tenure of the women directors was only 3.1 years, and only 27 percent of total female directors had a tenure above 4 years. Hermalin \& Weisbach (1991) find that median tenure directors ( 4.5 years -10 years) will lead to higher firm performance when measured by Tobin's $Q$. They argue directors with low tenure (less than 4.5 years) do not seem to affect profitability positively, yet in contrast; directors with tenure more than 10 years tend to reduce profitability.

Another plausible explanation is women in the boardroom, as a minority, may decide to adapt and blend into the male director's circle, the majority. Female directors will follow how male director's work and make similar decisions. Thus, female director's potential performance effect will not be different from male director's performance (Rose, 2007). This notion is also supported by Prihatiningtias (2012) who interviewed directors in financial institution in Indonesia and found female directors admit imitating men's working styles. Thus, the difference between female and men's working style might not be perceived anymore.

Moreover, we also find no relationship between both female commissioners and committee with bank's performance. We found no research in Indonesia that addresses the impact of gender diversity on committee board on firm performance. However, our finding is similar to Carter et al (2010), who did not find significance association between gender diversity in board and committee and firm performance in US firms. There are several plausible rationales why gender diversity in supervisory 
board in this sample does not affect the firm performance. First, women are less represented in supervisory boards. Only 37 percent of the dataset has one female commissioners (in Indonesia case, directors in supervisory boards are called commissioners) and 5 percent from dataset has two female commissioners. This can be explained because females are more risk averse than men (Croson \& Gneezy, 2009; Niederle \& Vesterlund, 2007; Jianakoplos \& Bernasek, 1998; Joecks et al., 2012). Thus, they are reluctant to be in or to fill the position in the boardroom. In Indonesia, the patrilineal system is still dominant in social life, where the man, husband or father has control over the family members and is main decision maker (Kusumastuti et al., 2007). Without his approval, women are not permissible to work in the company or even be commissioners. Another reason of the low percentage of women also relates to the argument that there is not sufficient "critical mass" of women in supervisory board to have much impact on bank's performance. According to Joecks et al. (2012), there should be a "critical mass" of female on the board to realise the diversity benefit. They indicate the range of critical mass should be about 30 percent of female on the board. Similarly, Torchia et al. (2011) found female in board room achieve "critical mass" when at least three women sit on a board that consists of 612 directors. They also indicated that female directors who achieve "critical mass" have a higher level of innovativeness, are able to challenge the management action and work collaboratively, which that will bring benefits to the company. In our findings, the numbers of female commissioners in each banks in the samples are mostly only one to two with the board size range from 5-20. Thus, referring to Torchia et al. (2011) discussion about the "critical mass", our sample does not achieve the threshold. Similarly, according to Joecks et al. (2012) discussion about the "critical mass" percentage, our sample only consists a few banks (10 percent of the observations) that have a proportion of female above 30 percent on the board. Thus, critical mass in female commissioners is hardly achieved in this sample, which results in their having no impact on firm performance.

Another plausible rationale is the nature of female commissioners and committees are independent, within which they are obliged to monitor and advise well for the management board to be able to operate the company in a good manner. In another word, gender does not play a pivotal role in both supervisory and committee boards. This supports the outcome of the research conducted by Prihatiningtias (2012), where she suggests that there is no significance different between female and male working style as commissioners in monitoring and advising the board of directors. Thus, female commissioners and committees have no impact on firm performance.

To summarize, in this research we do not find any evidence that gender diversity in management, supervisory, and committee board have an impact on bank's financial performance after controlling for unobserved firm heterogeneity and addressing reverse causality. Thus, $H_{1}, H_{2}$ and $H_{3}$ are rejected.

\section{Conclusion}

There is a growing literature that has examined the relationship between gender diversity and firm performance in Anglo Saxon, European Continental countries, yet very few in developing countries. Thus, the primary objective of this research was to provide empirical evidence as to whether gender diversity influences bank's financial performance in Indonesia. We used a sample from banks listed in the Indonesia Stock Exchange in 2011-2016. Bank's financial performances were measured with Return on Asset (ROA) and Capital Adequacy Ratio $(C A R)$, following the OJK's regulation. After using both fixed and random effect regression for Model 1 and 2 respectively, and taking into account the endogeneity problem, we found no evidence about the relationship between gender diversity in management, supervisory, and committee boards and 


\section{The impact of gender diversity in the boardroom on banks performances}

Siti Farhana

improved firm performance. Our findings are corroborated by a prior study by Fathonah (2018) who also examined the impact of gender diversity (using current ratio) in non-financial companies in Indonesia. Our results indicate the number of female directors in management, supervisory, and committee board does not necessary increase or decrease the firm performance. Therefore, their presence on board is deemed as insignificant on firm performance. We also find higher leverage tends to decrease CAR. To increase the robustness of our result, we used alternative measurement for bank's performance and gender diversity. We used ROE for bank's performance proxy and dummy variable for the presence of the women. Based on robustness test, our results from main regression remain robust, as we still found no significant link between gender diversity with firm performance.

However, this research is subject to some caveats. First, this research only used banks listed in IDX as a sample, thus the result cannot be generalised to other industries. Future studies need to expand the scope to non-bank industries. However, variable such as regulation should be taken into account because each industry has their own regulations. Second, we ruled out the banks not listed in IDX. Future studies can include all banks regardless of listing, to gain further insight from small banks because OJK's regulation are mandated to all banks. Third, we addressed the possibility of endogeneity issue by applying firm-fixed effect regression. Econometric textbook suggests this regression but there may be a drawback, such as producing unbiased estimates because we assume the unobservable firm characteristics are constant over time. Thus, future study should find another alternative regression model to address endogeneity issue, for example by applying two-stage instrument variables. In this research, we did not use two-stage instrument variables because it is difficult to find instrument variables due to limited information published in annual reports in Indonesia.

\section{Acknowledgement}

We would like to thank Prof. Yuval Milo from Warwick Business School for his supervising in writing this paper. We would also thank to Indonesian Endowment Fund for Education Scholarship (LPDP) from the Ministry of Finance, Indonesia for funding this research.

\section{References}

Ali, M., Ng, Y., \& Kulik, C. (2014). Board age and gender diversity: A test of competing linear and curvilinear predictions. Journal of Business Ethics, 125(3), 497-512. https://doi.org/10.1007/s10551-013-1930-9

Bank Indonesia. (2011). 70\% bank di Indonesia dimiliki keluarga, rawan pembobolan. Detik.com.

Beames, C. (2016). Identifying critical roles, easier said than done! Whitepaper advances workforce strategies. Retrieved from:

https://www.crforum.co.uk/research-and-resources/identifying-critical-roles-easier-said-than-done/

Bear, S., Rahman, N., \& Post, C. (2010). The impact of board diversity and gender composition on corporate social responsibility and firm reputation. Journal of Business Ethics, 97(2), 207-221. https://doi.org/10.1007/s10551-010-0505-2

Carter, D., D’Souza, F., Simkins, B., \& Simpson, W. (2010). The gender and ethnic diversity of US boards and board committees and firm financial performance. Corporate Governance: An International Review, 18(5), 396-414. https://doi.org/10.1111/j.1467-8683.2010.00809.x 
Carter, D., Simkins, B., \& Simpson, W. (2003). Corporate governance, board diversity, and firm value. The Financial Review, 38(1), 33-53. https://doi.org/10.1111/1540-6288.00034

Campbell, K., \& Vera, A. M. (2008). Gender diversity in the boardroom and firm financial performance. Journal of Business Ethics, 83(3), 435-451. https://doi.org/10.1007/s10551-007-9630-y

Claes, M. T. (1999). Women, men, and management styles. International Labour Review, 138(4), $431-446$. https://doi.org/10.1111/j.1564-913X.1999.tb00396.x

Credit Suisse. (2012). Gender diversity and corporate performance. Retrieved from: https://www.calstrs.com/csri_gender_diversity_and_corporate_performance.pdf

Croson, R., \& Gneezy, U. (2009). Gender differences in preferences. Journal of Economic Literature, 47(2), 448-474. https://doi.org/10.1257/jel.47.2.448

Darmadi, S. (2013). Do women in top management affect firm performance? Evidence from Indonesia. Corporate Governance: The International Journal of Business in Society, 13(3), 288-304. https://doi.org/10.1108/cg-12-2010-0096

Ellwood, S., \& Garcia-Lacalle, J. (2015). The influence of presence and position of women on the boards of directors: The case of NHS Foundation Trusts. Journal of Business Ethics, 130(1), 69-84. https://doi.org/10.1007/s10551-014-2206-8

Farag, H., \& Mallin, C. (2016). The impact of the dual board structure and board diversity: Evidence from Chinese Initial Public Offerings (IPOs). Journal of Business Ethics, 139(2), 333-349. https://doi.org/10.1007/s10551-015-2649-6

Farrell, K., \& Hersch, P. (2005). Additions to corporate boards: The effect of gender. Journal of Corporate Finance, 11(1-2), 85-106. https://doi.org/10.1016/j.jcorpfin.2003.12.001

Fathonah, A. N. (2018). Pengaruh gender diversity dan age diversity terhadap kinerja keuangan. Jurnal Riset Akuntansi dan Keuangan, 6(3). https://doi.org/10.17509/jrak.v6i3.13941

FSB. (2013). Recovery and resolution planning for systemically important financial institutions. Retrieved from: http://www.fsb.org/wp-content/uploads/r_130716b.pdf?page_moved=1

Garcia-Meca, E., García-Sánchez, I., \& Martínez-Ferrero, J. (2015). Board diversity and its effects on bank performance: An international analysis. Journal of Banking \& Finance, 53, 202-214. https://doi.org/10.1016/j.jbankfin.2014.12.002

Ghosh, S. (2017). Why is it a man's world, after all? Women on bank boards in India. Economics System, 41(1), 109-121. https://doi.org/10.1016/j.ecosys.2016.05.007

Gulamhussen, M. A., \& Santa, S. F. (2015). Female directors in bank boardrooms and their influence on performance and risk-taking. Global Finance Journal, 28(C), 10-23. https://doi.org/10.1016/j.gfj.2015.11.002

Harrison, D. A., \& Sin, H. P. (2006). What is diversity and how should it be measured? Handbook of Workplace Diversity, 192-217. https://doi.org/10.4135/9781848608092.n9

Hermalin, B., \& Weisbach, M. (1991). The effects of board composition and direct incentives on firm performance. Financial Management, 20(4), 101. https://doi.org/10.2307/3665716

Hermalin, B., \& Weisbach, M. (2003). Boards of directors as an endogenously determined institution: A survey of the economic literature. Federal Reserve Bank of New York Economic Policy Review, 9(1), 726. https://doi.org/10.2139/ssrn.233111 


\section{The impact of gender diversity in the boardroom on banks performances}

Siti Farhana

Jensen, M. (1993). The modern industrial revolution, exit, and the failure of internal control systems. The Journal of Finance, 48(3), 831-880. https://doi.org/10.1111/j.1540-6261.1993.tb04022.x

Jianakoplos, N. A., \& Bernasek, A. (1998). Are women more risk-averse? Economic Inquiry, 36(4), 620-630. https://doi.org/10.1111/j.1465-7295.1998.tb01740.x

Joecks, J., Pull, K., \& Vetter, K. (2012). Gender diversity in the boardroom and firm performance: What exactly constitutes a "critical mass?". Journal of Business Ethics, 118(1), 61-72. https://doi.org/10.1007/s10551-012-1553-6

Kanter, R. (1977). Men and Women of the Corporation. New York: Basic Books.

Komite Nasional Corporate Governance (KNKG), (2006). Indonesia’s Code of Corporate Governance. Jakarta: KNKG.

Kusumastuti, S., Supatmi, \& Sastra, P. (2007). The impact of board diversity on firm value: Corporate governance perspectives. Journal of Accounting and Finance, 9(2), 88-98. https://doi.org/10.9744/jak.9.2.pp.\%2088-98

Low, D., Roberts, H., \& Whiting, R. (2015). Board gender diversity and firm performance: Empirical evidence from Hong Kong, South Korea, Malaysia and Singapore. Pacific-Basin Finance Journal, 35, 381401. https://doi.org/10.1016/j.pacfin.2015.02.008

Marinova, J., Plantenga, J., \& Remery, C. (2015). Gender diversity and firm performance: Evidence from Dutch and Danish boardrooms. The International Journal of Human Resource Management, 27(15), 1777-1790. https://doi.org/10.1080/09585192.2015.1079229

McKinsey, 2012. Women matter: An Asia perspective. Retrieved from: http://wfa.ust.hk/women_matter_asia_files/Women_Matter_Asia.pdf

Melón-Izco, Á., Ruiz-Cabestre, F., \& Ruiz-Olalla, M. (2020). Diversity in the board of directors and good governance practices. Economics and Business Letters, 9(2), 97. https://doi.org/10.17811/ebl.9.2.2020.97-105

Mori, N. (2014). Directors' diversity and board performance: Evidence from East African Microfinance Institutions. Journal of African Business, 15(2), 100-113. https://doi.org/10.1080/15228916.2014.920654

Niederle, M., \& Vesterlund, L. (2007). Do women shy away from competition? do men compete too much? The Quarterly Journal of Economics, 122(3), 1067-1101. https://doi.org/10.1162/qjec.122.3.1067

Otoritas Jasa Keuangan (OJK). (2014). Peraturan Otoritas Jasa Keuangan No.33/POJK.05/2014 tentang Direksi dan Komisaris Bank Umum. Jakarta. Indonesia.

Prihatiningtias, Y. (2012). Gender diversity in the board room and firm performance: evidence from Indonesian publicly listed financial firms. European Journal of Economics, Finance, and Administrative Sciences. https://doi.org/10.1.1.453.9880

Pudjiastuti, W., \& Mardiyah, A. (2007). The influence of board structure on firm performance. Retrieved from: http://pdeb.fe.ui.ac.id/?p=7448

PWC. (2013). How corporate functions can add value in a new strategic era. Retrieved from: https://www.strategyand.pwc.com/media/file/Strategyand The-New-Functional-Agenda.pdf

Rao, K., \& Tilt, C. (2015). Board composition and corporate social responsibility: The role of diversity, gender, strategy, and decision making. Journal of Business Ethics, 138(2), 327-347. https://doi.org/10.1007/s10551-015-2613-5 
Romano, G., Ferretti, P., \& Quirici M. C. (2012). Corporate governance and performance in Italian banking groups. Managerial Auditing Journal, 27(7), 622-638.

Rose, C. (2007). Does female board representation influence firm performance? The Danish evidence. Corporate Governance an International Review, 15(2), 404-413. https://doi.org/10.1111/j.1467-8683.2007.00570.x

Shrader, C. B., Blackburn, V. B., \& Iles, P. (1997). Women in management and firm financial performance: an exploratory study. Journal of Managerial Issues, 9(3), 355-372.

Stendardi, E., Graham, J., \& O’Reilly, M. (2006). The impact of gender on the personal financial planning process. Humanomics, 22(4), 223-238. https://doi.org10.1108/08288660610710746

Thomsen, S., \& Conyon, M. (2012). Corporate Governance: Mechanism and Systems. New York: McGraw-Hill.

Torchia, M., Calabrò, A., \& Huse, M. (2011). Women directors on corporate boards: From tokenism to critical mass. Journal of Business Ethics, 102(2), 299-317. https://doi.org/10.1007/s10551-011-0815-z

Van Knippenberg, D., De Dreu, C., \& Homan, A. (2004). Work group diversity and group performance: An integrative model and research agenda. Journal of Applied Psychology, 89(6), 1008-1022. https://doi.org/10.1037/0021-9010.89.6.1008

World Bank. (2010). Corporate Governance Country Assessment: Indonesia. Report on the Observance of Standards and Codes (ROSC). 